\title{
The Potency of Binahong Leaves (Anredera cordifolia (Ten.) Steenis) to Recovery Process of Wound in The Livestock
}

\author{
Rita Purwasih $^{1, a)^{*}}$, Fika Ayu Safitri ${ }^{1, \text { b) }}$ dan Wiwik Endah Rahayu ${ }^{1, c)}$ \\ ${ }^{1}$ Jurusan Agroindustri Politeknik Negeri Subang \\ Jalan Arief Rahman Hakim No. 08 (Islamic Centre) Cigadung Subang-Jawa Barat \\ Telp. (0260) 417648, Fax. (0260) 417628 \\ a) rita.purwasih@polsub.ac.id \\ b)fikapolsub@gmail.com \\ c)windayu.sk@gmail.com

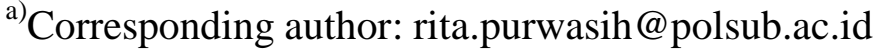

\begin{abstract}
Anredera cordifolia (Ten.) Steenis, in Indonesian is binahong, is a creeping plant with a length can reach 6 meters. Binahong originated from the United Stated and be classified in Family Basellaceae. In Indonesia, binahong often be used for traditional medicines to treat diabetes, relieve shortness of breath, stabilize blood pressure, coughing and vomiting blood, lung disease, accelerate wound healing process, restoring bruised, headache, hives, immune system, nose bleeding, prevent stokes and health problems after the surgery and childbirth. Binahong contains several active compounds, such as saponins, alkaloids, polyphenols, flavonoids, and glycosides that have an effect on the wound healing process. The extract of binahong leaf is made to retain the active compound content which is inside the leaf binahong in order to still have effect as anti-inflammatory, antioxidant, antibacterial, and as an analgesic. The purpose of this review is to educate the public about the benefits of leaves binahong and examine some researches related to the effects of leaf binahong on the health of livestock. Several studies have been conducted to prove that the leaf extract binahong positively influence on the process of wound healing in a rabbit uterine post partum; wound healing Staphylococcus aureus infection in mice; reduction of surface area burns Sprague Dawley rats; re-epithelialization of the epidermis in burns Sprague Dawley rats; accelerate the healing of cuts in the duration of swiss Webster male mice; test the effectiveness of binahong leaf extract ointment (Anredera cordifolia (Ten.) Steenis) in rabbits (Oryctolagus cuniculus) were infected with the bacteria staphylococcus aureus. The conclusion of this review article is binahong leaf extract can accelerate the wound healing process in animals that can be potentially as a treatment alternative.
\end{abstract}

Keywords: leaves binahong extract, wound healing

\section{INTRODUCTION}

The wound is a destruction of unity or network components that can cause damaged or loss of tissue substance. In general, there are two kind of wound, there are open and closed wound. Open wounds can contact the outside environment of the body, such as, abrasions, burns, etc. The closed wound cannot lead body to contact the outside environment, such as a bruise. The wound cause partial or complete loss of function organ, sympathetic stress response, blood clots, bleeding, and cell death, as well as the most risky is bacterial contamination. The wound healing process is complex and dynamic process as a result of continuity reverting and function of body anatomy. Wound healing process itself involves several factors: bacterial infections, nutritional deficiencies, type of injury, not in accordance with use of drugs, the movement of the injured area, the location of the wound and tissue in the wound. These factors influence the rate of wound healing. 
Anredera cordifolia (Ten.) Steenis, better known name is binahong, is a traditional medicine that used by the community as a wound healing drug in the past. People use binahong to heal wounds, the application of the extract depends on the wounds (Manoi, 2009; Hadian, 2010). Another affect of binahong is not only the wound healing process but also have the ability as an antibacterial. Many studies examined the effect of binahong in the healing process. The purpose of this review is to educate the public about the benefits of leaves binahong and examines some related research to affect of leaf binahong to animal health, in particular wound healing process.

\section{BINAHONG (Anredera cordifolia (Ten.) Steenis)}

Binahong is classified in Basellaceae Family and originated from the United Stated. Binahong, is a creeping plant with a length can reach \pm 5meters, rhizomes roots, soft stems, cylindrical, intertwined and reddish. The leaves is out of on the stem, single leaf, short-stemmed, arranged alternate, green, and will be formed a tuber or rhizome rough-textured at the age of 3 years, and can grow well in tropical or subtropical (Walters, 1989; Hadian, 2010).

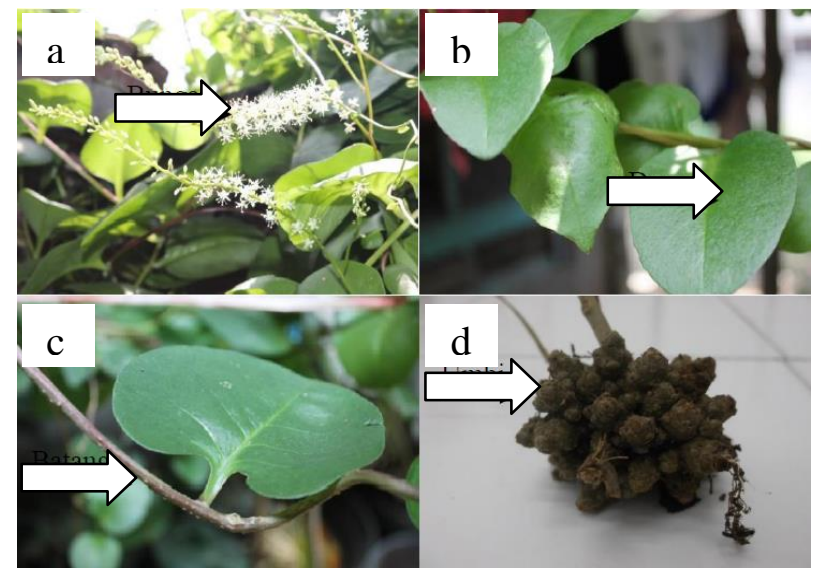

Figure 1. Part of Binahong (a. flower; b. leaves; c. stem; d. tuber)

Binahong is used as a traditional medicine, including healing burns, wounds after surgery, winding healing post partum, etc. The binahong treatments are different in each problem. For example, The burns need 10 leaves binahong/day, Surgery wound needs 20 leaves/day, and post partum needs 7 leaves/day (Manoi, 2009; Hadian, 2010). The extract Binahong leaf is made to retain the active compound in binahong that has an effect as anti-inflammatory, antioxidant, antibacterial, and as an analgesic. The effect is caused by some compenent in binahong, such as saponins, flavonoids, terpenoids, steroids and alkaloids.

\section{RESEARCH RELATED TO THE BINAHONG POTENTIAL IN THE PROCESS OF HEALING WOUNDS}

There are many studies conducted to assess the efficacy binahong in wound healing in livestock, some of which are as follows:

\subsection{The ffects of Ethanol Extract in Leaf Binahong (Anrederan cordifolia (Ten.) Steenis) in the duration of Accelerating Wound Healing in Mice Sayat Male Swiss Webster}

Research conducted by Hartono et al. (2011) aimed to assess the effect of ethanol extracts of leaves binahong (EEDB) can speed up the duration of the wound healing process sayat. The treatment in this study was conducting in three groups, they are smearing binahong leaf ethanol extract at different of concentration 5\%; 10\%; and 20\% and the negative control group were treated with Carboxy Methyl Cellulose (CMC) 1\%. The results of this study are binahong leaf extract 
ethanol with higher concentrations can accelerate the healing duration of cuts in male Swiss Webster mice, and the duration is the fastest application of ethanol extract of leaves binahong with a concentration of $20 \%$.

\subsection{The Effectiveness of Binahong Ointment Leaf Extract (Anredera cordifolia (Ten.) Steenis) on Rabbit (Orytolagus cuniculus) were infected by Staphylococcus aureus bacteria}

The research was conducted by Paju et. al. (2013) aims to determine the effectiveness of binahong leaf extract ointment on the wound infected by the bacteria Staphylococcus aureus and to know the effectiveness of ointment binahong leaf extract as antibacterials at different concentration of $10 \% ; 20 \%$; and $40 \%$. The conclusion of this study is the application of leaf extract binahong at $10 \%$ concentration of extract has a healing effect, while at a concentration of $20 \%$ and $40 \%$ are more effective than $10 \%$ as a healing effect. It means that there are differences in effectiveness at each concentration, the higher the concentration of leaf extract binahong given will provide a more effective healing effect.

\subsection{The Effect of Anredera cordifolia (Ten.) Steenis Supplementation on Uterine Involution Process Evaluated by Oestrus Post Partum Behavior and Ferning}

Furthermore, research conducted by Purwasih et. al. (2014) aims to determine the effect of Anredera cordifolia (Ten.) Steenis supplementation on the process of uterine involution in rabbits. Grouping in this study is the negative control group, without supplementation Anredera cordifolia (T1); supplementation Anredera cordifolia 2 days before parturition (T2); supplementation Anredera cordifolia 2 days after parturition (T3); Award supplementation Anredera cordifolia 2 days before until 2 days after parturition (T4). The result of research is giving Anredera cordifolia supplementation can accelerate postpartum estrus in rabbits, characterized by changes in behavior, description of mucus ferning saliva, cervical mucus and the best treatment is T4.

\subsection{The Effect of Leaf Extract Ointment Binahong (Anredera cordifolia (Tenore) Steenis) Re- epithelialization of the epidermis in Rat Burn Injuries Sprague dawley}

The purpose of this research is to know the effect of leaf extract binahong the healing of burns. The treatments are grouped on the positive control (silver sulfatiazin Award); negative control (ointment base); anointment binahong extract 10\% (T1); anointment binahong extract 20\% (T2); and anointment binahong extract $40 \%$ (T3). Results from this study is the lubrication binahong leaf extract with concentration of $10 \%, 20 \%$ and $40 \%$ and re-epithelialization, and the average reepithelialization in T2 and T3 is better than the positive control (Ahliadi, 2014).

\section{Binahong Content}

The efficacy of binahong surveyed is not separated from the active compound contained in binahong. Compounds contained in every part of the plant binahong based on the results of chemical analysis are as follows: 
Table 1. Analyze of Chemical Contain in Binahong (Astuti et al., 2011).

\begin{tabular}{|c|c|c|c|c|c|c|}
\hline No & Part of & \multicolumn{5}{|c|}{ Chemical contain } \\
\cline { 3 - 7 } & Binahong & Saponin & Flavonoid & Terpenoid & Steroid & Alkaloid \\
\hline 1. & Leat & + & + & + & + & + \\
\hline 2. & Stem & + & + & + & + & + \\
\hline 3. & Tuber & + & + & + & - & + \\
\hline 4. & Flower & + & + & + & - & - \\
\hline
\end{tabular}

Note $:+$ (there is bioactive component)

- (there is no bioactive component)

Saponin function as cleaners and antiseptics to prevent the growth of microorganisms that occur in the wound so that the wound did not experience severe infections other than the saponin is able to stimulate the formation of collagen I, which is a protein that plays a role in wound healing (Hartono et al., 2010; Paju et al., 2013). Flavonoids contain lipofilik protein that will damage the membrane cell because flavonoid will damage the microbial cell wall membrane so the metabolites within the cell will be out, resulting in the death of microbes (Noorhamdani et al., 2010). Triterpenoids strengthen the endurance has the function of cells to infection and repair the damaged cells so the cells can regenerate properly (Guyton dan Hall, 1997). Alkaloids have the ability as an antibacterial by interfering the bacterial cell constituent components (peptidoglycan), so the layer of the cell wall are not fully formed and it caused the death of these cells (Robinson, 1995; Darsana et al., 2012). Vitamin C (ascorbic acid) in binahong has a function to maintain the cell membrane, increase resistance to infection, and accelerate wound healing. Moreover, vitamin $\mathrm{C}$ acts as an antioxidant to activate prolil hydroxylase enzymes that support hydroxylation step in the formation of collagen in wound healing (Guyton dan Hall, 1997).

\section{CONCLUSION}

The conclusions of this review is binahong has various active compounds and its leaf extract can accelerate the wound healing process so that the leaves has a potential as alternative treatment for livestock.

\section{REFERENCES}

[1] S.S. Ahliadi, "Pengaruh Salep Ekstrak Binahong (Anredera cordifolia (Tenore) Steenis) terhadap Re-epitelisasi Epidermis pada Luka Bakar Tikus Sprague dawley," Skripsi, Program Studi Pendidikan Dokter, Fakultas Kedokteran dan Ilmu Kesehatan, UIN Syarif Hidayatullah Jakarta, 2014.

[2] S.M. Astuti,A.M.M. Sakinah, B.M.R. Andayani, and A. Risch. Determination of Saponin Compound from Anredera cordifolia (Ten) Steenis Plant (Binahong) to Potential Treatment for Several Diseases. (J. Agric. Sci. 2011)3(4) pp.224-232.

[3] I. G. O. Darsana, I . N. K. Besung, and H. Mahatmi. Potensi daun binahong (Anredera cordifolia (Tenore) Steenis) dalam menghambat pertumbuhan bakteri Escherichia coli secara in vitro. (Fakultas KedokteranHewan, Universitas Udayana. Indonesia Medicus Veterinus, 2012), 1 (3) : pp. 337 - 351.

[4] Guyton dan Hall. Buku Ajar Fisiologi Kedokteran. Ed. 9. (EGC, Jakarta, 1997.), translated by I. Setiawan.

[5] B.T. Hadian, "Perencanaan Buku Media Informasi tentang Manfaat Tanaman Binahong untuk Terapi Herbal pada Penyembuh Luka". Tesis.Universitas Komputer Indonesia, Bandung, 2010.

[6] Hartono, E.A., S.U. Sugeng, dan S. Puradisastra. 2011. Efek Ekstrak Etanol Daun Binahong (Anredera cordifolia (Ten.) Steenis) dalam Mempercepat Durasi Penyembuhan Luka Sayat pada Mencit Swiss Webster Jantan. Fakultas Kedokteran Universitas Kristen. Maranatha, Bandung.

[7] F. Manoi, and Ballitro, "Binahong (Anredera cordifolia) Sebagai Obat" (Warta Penelitian dan Pengembangan Tanaman Industri, 2009), 15 (1): pp. 3-6.

[8] A. Noorhamdani, R. Setyohadi, dan A. Fawzi. Uji Efektifitas Ekstrak Daun Binahong (Anredera cordifolia (ten.) sebagai Antimikroba terhadap Bakteri Klebsiella pneumoniae secara in Vitro. (Jurnal Penelitian, Malang, 2010), pp. 1-12.

[9] N. Paju, P.V.Y. Yamlean., and N. Kojong. Uji Efektivitas Salep Ekstrak Daun Binahong (Anredera Cordifolia (Ten.) Steenis) pada Kelinci (Oryctolagus cuniculus) yang Terinfeksi Bakteri Staphylococcus aureus (Jurnal Ilmiah Farmasi , UNSRAT, 2013), 2(1): pp, $2302-2493$. 
[10] Purwasih, R., E.T. Setiatin and D. Samsudewa. The Effect of Anredera cordifolia (Ten.) Steenis Supplementation on Uterine Involution Process Evaluated by Oestrus Post Partum Behavior and Ferning. (J.Indonesian Trop.Anim.Agric., Semarang, 2014), 39(1): pp. 17-22.

[11] T. Robinson, Kandungan Organik Tumbuhan Tinggi. (Penerbit Institut Teknologi Bandung, Bandung, 1995), translated by K. Padmawinata.

[12] S.M. Walters, The European Garden Flora. Vol. 3. (Dicotyledons (part 1), Cambridge University Press, Cambridge, 1989), pp. 17. 